\title{
OBTAINING AND CHARACTERIZATION OF A SELECTIVE PELARGONIUM GRAVEOLENS L'HÉR. DRY EXTRACT WITH POTENTIAL THERAPEUTIC ACTIVITY IN METABOLIC DISEASES
}

\author{
ALEXANDRA FILARETA NEAGU ${ }^{1 \#}$, TEODORA COSTEA ${ }^{2 *}$, IOANA NENCU ${ }^{2 \#}$, LIGIA \\ ELENA DUȚU ${ }^{2 \#}$, MARIA LIDIA POPESCU $^{2 \#}$, OCTAVIAN TUDOREL OLARU ${ }^{3 \#}$, CERASELA \\ ELENA GÎRD ${ }^{2 \#}$
}

"Carol Davila" University of Medicine and Pharmacy, Faculty of Pharmacy, 6 Traian Vuia Street, 020956, Bucharest, Romania

${ }^{I}$ Analytical Chemistry Department,

${ }^{2}$ Pharmacognosy, Phytochemistry and Phytotherapy Department,

${ }^{3}$ Pharmaceutical Botany and Cellular Biology Department

*corresponding author: teodoracostea85@yahoo.com

\#All authors contributed equally.

Manuscript received: January 2018

\begin{abstract}
The aim of our study was the obtaining, phytochemical characterization, evaluation of antioxidant activity and cytotoxic effects of a selective dry extract obtained from indigenous Pelargonium graveolens L'Hér (rose geranium, rose scented geranium) aerial parts, with potential therapeutic activity in metabolic diseases (diabetes mellitus, dyslipidaemia). Rose geranium flowers, leaves and aerial parts quality were determined by means of spectrophotometric methods (quantitative determination of anthocyanins, total phenolic content, flavones and phenolcarboxylic acids). The dry selective extract (obtained in 50\% ethanol) contains: $0.45 \mathrm{~g}$ anthocyanins (expressed as cyanine chloride) $/ 100 \mathrm{~g}$ dry extract and $45.73 \mathrm{~g}$ total phenolic content (expressed as tannic acid equivalents) $/ 100 \mathrm{~g}$ dry extract. HPLC (high performance liquid chromatography) analysis revealed the presence of epigallocatechin and catechin derivatives. The dry extract antioxidant capacity was assessed using $\mathrm{ABTS}^{\bullet+}\left(2,2^{2}\right.$-azinobis-(3-ethylbenzothiazoline6-sulfonic acid) free radical scavenger activity and ferric reducing power assay. Antioxidant activity was expressed as $\mathrm{EC}_{50}$ $(\mu \mathrm{g} / \mathrm{mL})$ (which represent the dry extract's concentration that inhibited $50 \%$ of ABTS $^{\circ+}$ activity/ the concentration that provides 0.5 absorbance for ferric reducing power assay $-\mathrm{EC}_{50}=17.53 \mu \mathrm{g} / \mathrm{mL} / \mathrm{EC}_{50}=74.43 \mu \mathrm{g} / \mathrm{mL}$ ). The extract induced dose and time dependent cytotoxic effect against Daphnia magna invertebrates. Our preliminary results offer encouraging premises for obtaining a phytomedicine with potential therapeutic effect in metabolic diseases.
\end{abstract}

\section{Rezumat}

Scopul lucrării a constat în obţinerea, caracterizarea fitochimică şi evaluarea activităţii antioxidante a unui extract uscat, selectiv obţinut din părţi aeriene de Pelargonium graveolens L'Hér (muşcată), cu potenţială activitate în tratamentul afecţiunilor metabolice (diabet zaharat, dislipidemie). Calitatea produselor vegetale (flori, frunze, parţi aeriene) a fost determinată prin metode spectrofotometrice (determinări cantitative pentru polifenoli totali, antociani, flavone, acizi fenolcarboxilici). Extractul hidroalcoolic uscat (obţinut în etanol 50\%) conţine 45,73 g polifenoli totali (exprimaţi în echivalenţi de acid tanic)/100 g extract uscat şi $0,45 \mathrm{~g}$ antociani (exprimaţi în echivalenţi de clorură de cianidol)/100 g extract uscat. Analiza HPLC (cromatografie de lichide de înaltă performanță) a evidenţiat prezenţa derivaţilor de catechol şi a epigalocatecholului. Activitatea antioxidantă a extractului a fost determinată pe baza capacităţii de scavenger a radicalului liber $\mathrm{ABTS}^{*+}$ (acidul 2,2'-azinobis-3-etilbenzotiazolin-6-sulfonic) şi pe baza capacităţii de reducere a ferului. Capacitate antioxidantă a fost evaluată pe baza $\mathrm{EC}_{50}(\mu \mathrm{g} / \mathrm{mL})($ concentrația extractului care inhibă cu 50\% activitatea radicalului liber/concentrația la care absorbanța are valoarea 0,5 pentru capacitatea de reducere a ferului $-\mathrm{EC}_{50}=17,53 \mu \mathrm{g} / \mathrm{mL} / \mathrm{EC}_{50}=74,43 \mu \mathrm{g} / \mathrm{mL}$ ). Toxicitatea extractului asupra nevertebratului Daphnia magna a fost dependentă de concentraţia şi timpul de incubare utilizat. Rezultatele obţinute oferă premise încurajatoare pentru obţinerea unui fitopreparat cu potenţiala utilizare în tratamentul afecţiunilor metabolice.

Keywords: total phenolic content, rose geranium, catechin, antioxidant capacity

\section{Introduction}

The genus Pelargonium comprises over 270 species, native to southern part of the African continent. It includes annuals, herbaceous perennials, shrubs and deciduous plants [23]. Pelargonium species (P. alpinum Eckl. \& Zeyh., P. luteum G. Don, P. zonale L'Hér ex Aiton, $P$. reniforme Curt., $P$. sidoides DC., etc.) are traditionally used in the treatment of diarrhoea, wounds, respiratory tract infections, liver complaints, gastroenteritis [23] or as ornamental plants [22]. Pelargonium graveolens L'Hér, known as rose geranium or rose scented geranium, is one the most studied Pelargonium species, due to its essential oil (commercially known as geranium oil) [23]. Rose geranium leaves and aerial parts are an important source of essential oil, phenolic 
compounds, coumarins and amines (methylhexanamine) $[19,23]$. The essential oil has a complex chemical composition, the main constituents are: linalool (0.4 $3.1 \%$ ), citronellol $(14.2-22.8 \%)$, citronellyformate $(11.40 \%)$, mentone $(2 \%)$, geraniol (26 - 50\%), geranial $(0.8 \%)$, geranyl valerate $(0.4 \%)$, neral $(0.3 \%)$, citral $(0.65 \%)$, isomenthone $(5.44 \%), \gamma$-cadinene $(0.5 \%)$, $\alpha$-muurolene $(0.2 \%)$, $\alpha$-humulene $(0.3 \%), \alpha$-pinene (1.08\%), limonene $(0.19 \%), \gamma$-terpinene $(2.41 \%), \gamma$ eudesmol (11.23\%), 1,8-cineole (0.6\%), ledene $(1.13 \%)$, germacrene $(1.71 \%), \beta$-elemene $(0.6 \%), 6,9$-guaiadiene (4.6\%), decanoic acid (3.4\%) and traces of camphene, $m$-cymene $[4,6,9,18]$. The essential oil chemical composition is influenced by different phenological stages, the highest concentration of geraniol and linalool was found at flowering [5]. Regarding phenolic compounds, rose geranium leaves are a source of tannins (epigallocatechin gallate), phenolcarboxylic acids (protocatechuic acid, $o$-coumaric and $p$-coumaric acids), flavones (myricetin-3-O glucoside, quercetin-3-Orhamnosyl $(1 \rightarrow 6)$ hexoside, quercetin-3-O-galactoside, kaempferol-3-O-glucoside) [2].

The essential oil and leaves have shown antibacterial, antifungic and antileishmanial effects $[3,8,9,21]$. Geranium oil has anti-inflammatory effects due to its moderate anti-lipoxygenase activity $[7,16]$. Recent research has shown that Pelargonium essential oil can effectively reduce anxiety during labour [10] and prevents oxidative testicular damage, similar to vitamin E, in mice exposed to deltamethrin pesticide [24]. Different extracts from rose geranium leaves/aerial parts showed hypoglycaemic, hypolipidemic [1], hepatoprotective [2] and anticholinesterase properties [15]. Taking into consideration the scientific data, the aim of our study was obtaining, phytochemical characterization, evaluation of antioxidant activity and cytotoxic effects of a selective dry extract obtained from indigenous rose geranium aerial parts, that might be used for the formulation of a phytomedicine with therapeutic activity in metabolic diseases (diabetes mellitus, dyslipidaemia).

\section{Materials and Methods}

\section{Material}

Leaves, flowers and aerial parts of Pelargonium graveolens were harvested from ecological crop, Romania, in 2017. The raw material was air-dried under shade and afterwards stored in laboratory conditions. Reagents and solvents

All reagents and solvents were purchased from Roth (Germany), unless otherwise stated.

\section{Methods}

Our research was performed in several steps: 1) evaluation of herbal products (leaves, flowers and whole aerial parts) quality; 2) obtaining and phytochemical characterization of a selective dry extract; 3 ) evaluation of the extract's antioxidant capacity;
4) assessment of rose geranium dry extract toxicity upon Daphnia magna invertebrates.

The evaluation of herbal products quality (1) (leaves = $\mathrm{PL}$, flowers $=$ PF, whole aerial parts $=$ PAP) was performed using spectrophotometric methods for determination of flavones, phenolcarboxylic acids, anthocyanins and total phenolic contents.

Preparation of samples for spectrophotometric determinations: $2 \mathrm{~g}$ of dried herbal products (flowers, leaves, whole aerial parts) was heated twice with $50 \mathrm{~mL}$ $50 \%$ ethanol $(\mathrm{v} / \mathrm{v})$ on a reflux condenser for $15 \mathrm{~min}$. After cooling, the solutions were filtered in a $100 \mathrm{~mL}$ volumetric flask and filled to mark with the same solvent.

Spectrophotometric assay of flavones, phenolcarboxylic acids and total phenolic contents was carried out as previously described [11]. For anthocyanins content, the determination was performed according to European Pharmacopoeia $7^{\text {th }}$ edition [26]. The following calibration curves have been used in order to determine the active substances content: rutin $(5.0-35.0 \mu \mathrm{g} / \mathrm{mL}$, $\left.\mathrm{R}^{2}=0.9998, \mathrm{n}=11\right)$, chlorogenic acid (0.0113 $\left.0.0527 \mathrm{mg} / \mathrm{mL}, \mathrm{R}^{2}=0.9998, \mathrm{n}=6\right)$, tannic acid (2.0 $\left.12.0 \mu \mathrm{g} / \mathrm{mL}, \mathrm{R}^{2}=0.9990, \mathrm{n}=10\right)$ and cyanine chloride (linearity range: $1,63-9,79 \mu \mathrm{g} / \mathrm{mL} \mu \mathrm{g} / \mathrm{mL}, \mathrm{R}^{2}=0.9990$, $\mathrm{n}=11)$.

Obtaining and phytochemical characterization of a selective rose geranium aerial parts dry extract (2) (PE). $800 \mathrm{~g}$ of whole aerial parts were heated twice with $50 \%$ ethanol (v/v) under a reflux condenser for $60 \mathrm{~min}$. The drug solvent ratio was 1:10 for the first extraction and 1:5 for the second one. After cooling, the combined filtrates were concentrated using a rotary evaporator (Buchi R 210-215) and then freeze dried (Christ Alpha 1-2/B Braun, BiotechInt. lyophylizator) to yield $184 \mathrm{~g}$ dry extract. The extraction yield is expressed as the percentage of the total mass of the dry extract (Mext without water content) with respect to the mass of the raw material (Mpv) loaded onto to the flask for solvent extraction: $\mathrm{Y} \%=(\mathrm{Mext} / \mathrm{Mpv}) \times$ 100 [25].

The same spectrophotometric determinations (as for step 1) have been used in order to determine the dry extract's chemical composition. High performance liquid chromatography (HPLC) analysis was carried out as previously described [11, 12]. Assays were performed using a $0.02 \%$ stock solution, prepared by dissolving the extract in $50 \%$ ethanol.

The dry extract's antioxidant capacity (3) was determined based on scavenger activity towards $\mathrm{ABTS}^{\circ+}(2,2$ azinobis-(3-ethylbenzothiazoline-6-sulfonic acid) free radical and ferric reducing power, as previously described $[11,20]$. The concentration range was $2-40$ $\mu \mathrm{g} / \mathrm{mL}$ (for $\mathrm{ABTS}^{\cdot+}$ method) and $65-3239 \mu \mathrm{g} / \mathrm{mL}$ (for ferric reducing power). The antioxidant activity was expressed as $\mathrm{EC}_{50}(\mu \mathrm{g} / \mathrm{mL})$, that represents the dry extract's concentration that inhibited $50 \%$ of $\mathrm{ABTS}^{\circ+}$ free radical activity or the concentration providing 
FARMACIA, 2018, Vol. 66, 4

0.5 absorbance (for ferric reducing power). $\mathrm{EC}_{50}$ $(\mu \mathrm{g} / \mathrm{mL})$ was determined graphically from the linear regression curve between percent (\%) ABTS inhibition/ Absorbance and concentration $(\mu \mathrm{g} / \mathrm{mL})$. Ascorbic acid was used as positive control.

The cytotoxicity of Pelargonium dry extract (4) was determined using Daphnia magna bioassay [11, 17]. The concentration range was $20-1500 \mu \mathrm{g} / \mathrm{mL}$ and lethality percentages were determined at $24 / 48 \mathrm{~h}$.

Statistical analysis

Data analysis was performed using Microsoft Excel 2007 (Microsoft Corp. USA) and GraphPad Prism v. 5.0. (GraphPad Software, USA).

\section{Results and Discussion}

Herbal products (flowers, leaves, whole aerial parts) quantitative analysis revealed that the highest phenolic content was found for flowers followed by aerial parts (Table I). For PF and PAP, we also determined a moderate anthocyanins content. Our results are similar to other authors research, that identified flavones and phenolcarbocylic acids in rose geranium leaves extracts [2]. Regarding total phenolic content, Dimitrova $\mathrm{M}$ et al found $8.23 \mathrm{~g}$ tannic acid/100 $\mathrm{g}$ fresh aerial parts for an aqueous extract obtained using decoction, as extraction method [8]. However, the comparison of our results with scientific data literature was difficult, since differences can occur due to herbal product's time of harvest, raw material type (dried/fresh) and extraction solvent. Taking into consideration the similar total phenolic content of whole aerial parts and flowers and the anthocyanins presence in geranium flowers, we have chosen to obtain a selective dry extract from PAP. The extraction yield was $23 \%$.

Table I

Spectrophotometric results for herbal products

\begin{tabular}{|l|c|c|c|}
\hline \multicolumn{1}{|c|}{ Active substance } & PF & PL & PAP \\
\hline Total phenolic content (g tannic acid /100 g herbal product) & $22.8150 \pm 1.398$ & $7.716 \pm 0.326$ & $16.1700 \pm 1.4982$ \\
\hline Flavones (g rutin/100 g herbal product) & nd & $0.3902 \pm 0.362$ & $0.5136 \pm 0.0981$ \\
\hline Phenol carboxylic acids (g chlorogenic acid/100 g herbal product) & $3.6910 \pm 0.458$ & nd & $1.307 \pm 0.137$ \\
\hline Anthocyanins (g cyanine chloride/100 g herbal product) & $1.0666 \pm 0.1548$ & nd & $0.2798 \pm 0.057$ \\
\hline
\end{tabular}

$\mathrm{PF}$ - rose geranium flowers; PL - rose geranium leaves; PAP - rose geranium aerial parts; nd - not determined; Results are mean \pm standard deviation (SD) $(\mathrm{n}=3)$

The dry extract chemical composition was determined by means of spectrophotometric and HPLC methods. According to our results PE dry extract is a rich source of phenolic compounds and anthocyanins (Figure 1). Our results are lower compared to Pradeepa M. et al that found $123 \mathrm{~g}$ tannic acid/100 $\mathrm{g}$ dry ethanolic extract, obtained from rose geranium leaves [21]. Based on retention time, we have identified the presence of tannins in PE dry extract (epigallocatechin and catechin derivatives) (Table II).

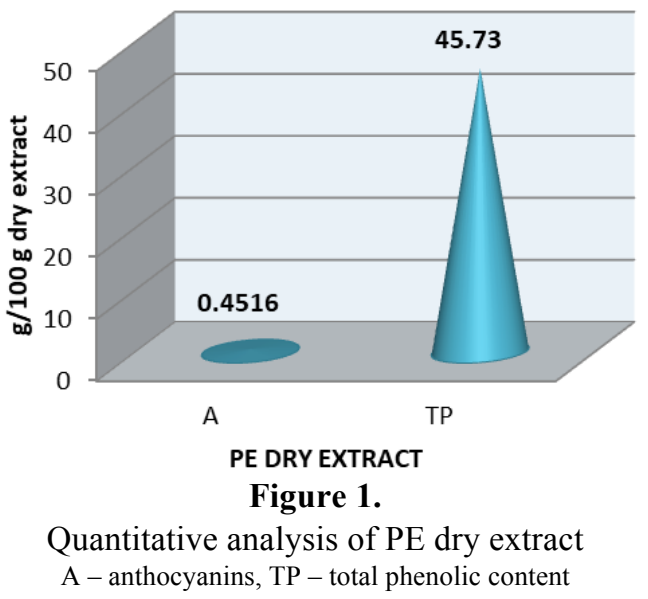

Our results are similar to Al-Sayed E. et al that identified epigallocatechin, epigallocatechin (dimer), epigallocatehin (trimer) and monogalloyl glucose in an ethanolic dry extract obtained from Pelargonium graveolens dried leaves [2].
Table II

HPLC analysis for PE dry extract

\begin{tabular}{|l|c|}
\hline \multicolumn{1}{|c|}{ Compound } & $\mathbf{R}_{\mathbf{t}}$ (min.) \\
\hline Epigallocatechin & 14.11 \\
\hline Catechin $\mathrm{D}_{1}$ & 2.81 \\
\hline Catechin $\mathrm{D}_{2}$ & 18.5 \\
\hline Catechin $\mathrm{D}_{3}$ & 19.1 \\
\hline
\end{tabular}

Pelargonium dry extract has scavenger activity towards $\mathrm{ABTS}^{\circ+}$ free radical and ferric reducing power capacity (Table III). For $\mathrm{ABTS}^{*+}$ method the antioxidant capacity was higher compared to our positive control (ascorbic acid) (Table III). The antioxidant activity of rose geranium leaves/aerial parts/essential oil was also reported by other authors, who have used different methods (2,2-diphenyl-1-picrylhydrazyl free radical scavenger activity - DPPH assay) [6, 16, 18]. Important antioxidant activity was also determined for other Pelargonium species (P. hispidum and P. zonale) [14].

Table III

Antioxidant capacity evaluation

\begin{tabular}{|l|c|c|}
\hline \multirow{2}{*}{ Sample } & \multicolumn{2}{|c|}{ METHOD $-\mathbf{E C}_{\mathbf{5 0}}(\boldsymbol{\mu g} / \mathbf{m L})$} \\
\cline { 2 - 3 } & $\mathbf{A B T S}^{++}$ & $\begin{array}{c}\text { Ferric reducing } \\
\text { power }\end{array}$ \\
\hline PE dry extract & $17.53 \pm 0.3396$ & $74.43 \pm 0.468$ \\
\hline Ascorbic acid & $60 \pm 0.009$ & $21 \pm 0.012$ \\
\hline
\end{tabular}

Our extract showed a low toxicity on Daphnia magna after $24 \mathrm{~h}$ and a moderate to high toxicity after $48 \mathrm{~h}$ of exposure (Table IV, Figures 2 and 3). After $24 \mathrm{~h}$, the 
extract was cytotoxic only at high concentrations $(1000-1500 \mu \mathrm{g} / \mathrm{mL})$. However, after $48 \mathrm{~h}$, toxicity was also observed for concentrations above $250 \mu \mathrm{g} / \mathrm{mL}$.

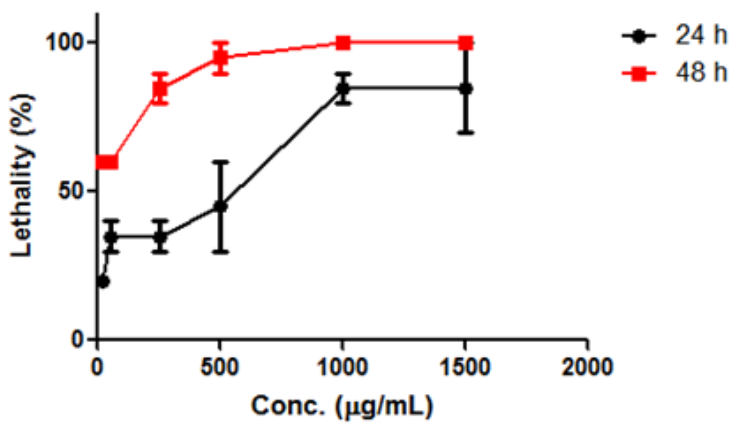

Figure 2.

Lethality on Daphnia magna versus concentration of extract

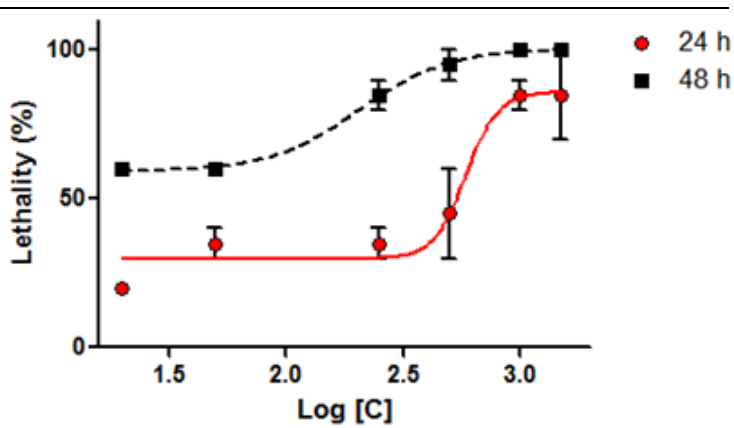

Figure 3.

Concentration-lethality curves for cytotoxic activity on Daphnia magna

We assume that cytotoxic effects are correlated with the total phenolic content, since it is well known that high amounts of phenolic compounds act as prooxidants and induce apoptosis [13]. $\mathrm{R}^{2}$ coefficients $(>0.8)$ are satisfactory, thus showing a good correlation between concentration and biological effect (Table IV).

Table IV

Cytotoxicity effect of PE on Daphnia magna

\begin{tabular}{|c|c|c|c|c|}
\hline Sample & Time of determination & $\mathbf{L C}_{\mathbf{5 0}}(\boldsymbol{\mu g} / \mathbf{m L})$ & $\mathbf{I C 9 5 \%}(\boldsymbol{\mu g} / \mathbf{m L})$ & $\mathbf{r}^{\mathbf{2}}$ \\
\hline Pelargonium dry extract & $24 \mathrm{~h}$ & 582.6 & $270.4-1255$ & 0.8449 \\
\cline { 2 - 5 } & $48 \mathrm{~h}$ & 203.3 & $137.8-299.9$ & 0.9716 \\
\hline
\end{tabular}

\section{Conclusions}

Pelargonium graveolens L'Hér aerial parts were phytochemically characterized by means of quantitative methods. The raw material was used to obtain a hydroethanolic (50\% ethanol) dry extract rich in catechin and anthocyanins derivatives. The dry extract showed good antioxidant activity. Pelargonium dry extract induced time and dose dependent toxicity upon Daphnia magna invertebrates. Future pre-clinical research is needed in order to determine the pharmacotoxicological profile, in view of obtaining a phytomedicine with potential therapeutic effect in metabolic diseases (diabetes mellitus, dyslipidaemia) treatment.

\section{References}

1. Afifi FU, Kasabri V, Abu-Dahab R, Abaza IM, Chemical composition and in vitro studies of the essential oil and aqueous extract of Pelargonium graveolens growing in Jordan for hypoglycaemic and hypolipidemic properties. Eur J Med Plants, 2014; 4(2): 220-233.

2. Al-Sayed E, Martiskainen O, El-Din SHS, Sabra ANA, Hammam OA, El-Lakkany NM, Protective effect of Pelargonium graveolens against carbon tetrachlorideinduced hepatotoxicity in mice and characterization of its bioactive constituents by HPLC-PDA-ESI-MS/ MS analysis. Med Chem Res, 2015; 24(4): 1438-1448.

3. Asgarpanah J, Ramenzanloo F, An overview of phytopharmacology of Pelargonium graveolens L. Ind J Tradit Know, 2015; 14(4): 558-563.

4. Badawy ME, Abdelgaleil SA, Composition and antimicrobial activity of essential oils isolated from
Egyptian plants against plant pathogenic bacteria and fungi. Ind Crops Products, 2014; 52: 776-782.

5. Boukhris M, Hadrich F, Chtourou H, Dhouib A, Bouaziz M, Sayadi S, Chemical composition, biological activities and DNA damage protective effect of Pelargonium graveolens L'Hér essential oils at different phenological stages. Ind Crops Products, 2015; 74: 600-606.

6. Ćavar S, Maksimović M, Antioxidant activity of essential oil and aqueous extract of Pelargonium graveolens L'Her. Food Control, 2012; 23(1): 263-267.

7. Chandra H, Farooq AH, Lipoxygenase inhibitory, antioxidant, and antimicrobial activities of selected essential oils. Asian J Pharm Clin Res., 2014; 7(4): 79-83.

8. Dimitrova M, Mihaylova D, Popova A, Alexieva J, Zapundzhieva T, Fidan H, Phenolic profile, antibacterial and antioxidant activity of Pelargonium graveolens leaves' extracts. Sci Bull (F) Biotechnologies, 2015; XIX: 130-135.

9. Essid R, Rahali FZ, Msaada K, Sghair I, Hammami M, Bouratbine A, Aoun K, Antileishmanial and cytotoxic potential of essential oils from medicinal plants in Northern Tunisia. Ind Crops Products, 2015; 77: 795-802.

10. Fakari FR, Tabatabaeichehr M, Kamali H, Fakari FR, Naseri M, Effect of inhalation of aroma of geranium essence on anxiety and physiological parameters during first stage of labor in nulliparous women: a randomized clinical trial. J. Caring. Sci., 2015; 4(2): 135-141.

11. Gîrd CE, Duţu LG, Costea T, Nencu I, Popescu ML, Olaru OT, Preliminary research concerning the obtaining of herbal extract with potential neuroprotective activity. Note I. Obtaining and characterization of a selective Origanum vulgare L. dry extract. Farmacia, 2016; 64(5): 680-687. 
12. Gîrd CE, Nencu I, Costea T, Duţu LE, Popescu ML, Ciupitu N., Quantitative analysis of phenolic compounds from Salvia officinalis L. leaves. Farmacia, 2014; 62(4): 649-657.

13. Haliwell B, Are polyphenols antioxidants or prooxidants? What do we learn from cell culture and in vivo studies? Arch Biochem Biophys., 2008; 476(2): 107-112.

14. Iancu $C$, Cioancă $\mathrm{O}$, Mircea $\mathrm{C}$, Mocanu M, Hăncianu M, Pelargonium sp.: Characterization of the polyphenols and their biological potential. Farmacia, 2016; 64(3): 333-338.

15. Jazayeri SB, Amanlou A, Ghanadian N, Pasala P, A preliminary investigation of anticholinesterase activity of some Iranian medicinal plants commonly used in traditional medicine. DARU J Pharmaceut Sci., 2014; 22(1): 17: 1-5.

16. Nadjib Boukhatem M, Kameli A, Amine Ferhat M, Saidi F, Mekarnia M, Rose geranium essential oil as a source of new and safe anti-inflammatory drugs. Libyan J Med., 2013; 8(1): 22520: 1-7.

17. Olaru OT, Venables L, Van de Venter M, Nitulescu GM, Margina D, Spandidos DA, Tsatsakis AM, Anticancer potential of selected Fallopia Adans species. Oncol Lett., 2015; 10(3): 1323-1332.

18. Pandey V, Patra DD, Crop productivity, aroma profile and antioxidant activity in Pelargonium graveolens L'Hér under integrated supply of various organic and chemical fertilizers. Ind Crops Products, 2015; 67: 257-263.

19. Pawar RS, Tamta H, Ma J, Krynitsky AJ, Grundel E, Wamer WG, Rader JI, Updates on chemical and biological research on botanical ingredients in dietary supplements. Anal Bioanal Chem., 2013; 405(13): 4373-4384.

20. Popescu ML, Costea T, Nencu I, Duţu LE, Gîrd CE, Polyphenols contents and antioxidant activity of some Romanian wild edible mushrooms. Farmacia, 2016; 64(2): 213-236.

21. Pradeepa M, Kalidas V, Geetha N, Qualitative and quantitative phytochemical analysis and bactericidal activity of Pelargonium graveolens L'Hér. Int J Appl Pharm., 2016; 8(3): 7-11.

22. Roeschenbleck J, Albers F, Müller K, Weinl S, Kudla $\mathrm{J}$, Phylogenetics, character evolution and a subgeneric revision of the genus Pelargonium (Geraniaceae). Phytotaxa, 2014; 159(2): 31-76.

23. Saraswathi J, Venkatesh K, Baburao N, Hilal MH, Rani AR, Phytopharmacological importance of Pelargonium species. J Med Plant Res., 2011; 5(13): 2587-2598.

24. Slima AB, Ali MB, Barkallah M, Traore AI, Allouche $\mathrm{N}$, Gdoura R, Antioxidant properties of Pelargonium graveolens L'Her essential oil on the reproductive damage induced by deltamethrin in mice as compared to alpha-tocopherol. Lipids Health Dis., 2013; 12(1): 30.

25. Yang CH, Li RX, Chuang LY, Antioxidant activity of various parts of Cinnamomum cassia extracted with different extraction methods. Molecules, 2012; 17: 7294-7304.

26. $* * *$ European Pharmacopoeia, $7^{\text {th }}$ edition, EDQM, Strasbourg, 2011, 1070. 